\title{
Relationship between soil moisture deficit and productivity of paddy lands in a major irrigation system in Intermediate zone of Sri Lanka
}

\author{
A.C.S. Perera ${ }^{*}$ E.R.N. Gunawardena ${ }^{1}$ and B.V.R. Punyawardena ${ }^{2}$ \\ Postgraduate Institute of Agriculture \\ University of Peradeniya \\ Sri Lanka
}

\begin{abstract}
This study is conducted to investigate the relationship between paddy productivity and soil moisture deficit in a selected irrigation scheme in the Intermediate zone of Sri Lanka. The availability of water for crop growth is estimated using a soil moisture balance equation using field data for a period from 2005 to 2014 to find the soil moisture deficit. A regression showed that relationship between paddy productivity and severity of soil moisture deficit in Yala season is not statistically significant. However, the decrease of paddy productivity during Maha season is influenced by both number of days of soil moisture stress and the total soil moisture stress and the results are found to be statistically significant. About $72 \%$ and $88 \%$ of the variation of paddy productivity can be explained by the total number of days with soil moisture stress and total soil moisture stress respectively.
\end{abstract}

Keywords: Irrigation water management, paddy productivity, soil moisture deficit, system productivity

\section{INTRODUCTION}

Paddy is one of the major users of world's developed fresh water resources since it is widely grown under irrigation. Paddy cultivation can be done under irrigated (lowland) or rainfed (upland or lowland) conditions. Rainfed paddy cultivation occupies about $45 \%$ of the global paddy cultivation and accounts for about $25 \%$ of the rice production (Tuong and Bouman, 2003). Lowland paddy cultivation in Asia is commonly transplanted or direct (wet) seeded into lowland paddy fields which are puddled. About 80 percent of freshwater in Asia is used for irrigated agriculture and paddy cultivation consumes more than half of it (Bhuiyan, 1992).

According to Inthapan and Fukai (1988), paddy plant (Oryza sativa L.) is particularly more sensitive to soil water deficit than other field crops and drought has affected its growth in about $50 \%$ of the world paddy production area (Hanson et al., 1990). Drought stress on plants has been reported to reduce the rice growth, adversely affect the photosynthesis, seedling biomass, stomatal conductance, plant water relation such as nutrient uptake and starch metabolism (Sarkarung et al., 1997). The grain yield of some rice genotypes could be reduced by up to $81 \%$ under drought, depending on the timing, duration and severity of the plant water deficit (Pantuwan et al., 2000). Since rice plants in general have a shallow root system, the amount of water that can be extracted from the root depth is relatively small

Department of Agricultural Engineering, Faculty of Agriculture, University of Peradeniya, Sri Lanka

2 Natural Resource Management Center, Department of Agriculture, Peradeniya, Sri Lanka

Corresponding author: chathup87@gmail.com 
(Fukai and Inthapan, 1988). The response of paddy yield to water stress depends on the timing of the drought because the sensitivity of the plant varies at different growth stages (Ekanayake et al., 1989). The studies conducted in the past have established relationships between rainfall and paddy yield at the macro (country) level (Zubair, 2002). However, the yield could be substantially different even if the same amount of water (i.e. rainfall and irrigation) is made available for paddy cultivation during a season at irrigation system level, because water management for paddy cultivation, which takes in to account the amount, frequency and timing has a profound effect on the final yield. That is one of the reasons for the difficulty in establishing a relationship with paddy yield with rainfall, irrigation or both at irrigation system level. Preliminary studies carried out by the authors have also indicated that there is hardly any relationship between paddy yield with total rainfall and irrigation or both.

As discussed above, the paddy yield depends on the availability of water to the plant. Therefore, the total production from an irrigation system is invariably depends on how best the irrigation water is managed conjunctively with the rainfall in order to achieve the highest water productivity. A study, therefore, was conducted to find the relationship between paddy productivity and soil moisture deficit in a selected irrigation scheme in the Intermediate zone of Sri Lanka. The findings would be useful in future research in view of the increased climatic variability (Perera et al., 2014) which also increases the soil moisture variability. In addition, it would also help to stress the fact that maintaining a suitable moisture regime within the soil profile is very important in ensuring high paddy productivity in irrigation systems rather than sticking to a fixed irrigation rotation based on historical data.

\section{MATERIALS AND METHODOLOGY}

\section{Study Area}

This study was conducted in the Hakwatuna Oya irrigation scheme, located in the upper catchment part of the Deduru Oya river basin in $\mathrm{IL}_{3}$ Agro Ecological Region (AER) $\left(7^{0} 46^{\prime} \mathrm{N}\right.$, $\left.80^{\circ} 26^{\prime} \mathrm{E}\right)$. Compared to other two regions in the Intermediate zone, $\mathrm{IL}_{3}$ receives the lowest amount of rainfall around 1,100 mm (Punyawardena, 2008). The rainfall contribution to this area is highest during Second Inter Monsoon (SIM) and North East Monsoon (NEM) seasons in the months of October and November facilitating paddy cultivation in Maha season with the aid of irrigation facilities. However, the Yala rains are not sufficient for successful rice cultivation. During the Yala season, the loose soils are used for dry sowing for maximum use of rainwater. The main rice growing soils in this region are Low Humic Glay and None Calcic Brown soils situated in undulating terrain (Punyawardena, 2008).

\section{Soil Moisture Balance}

The availability of water for crop growth can be estimated by balancing the moisture content in the soil using a water (moisture) balance equation as given below in equation 1;

$$
\Delta S=(I+P)-\left(Q_{r}+A E T+D\right)
$$

Where, P (water received by the rainfall) and I (irrigation) are the major inputs whilst, water losses from the soil includes runoff $\left(\mathrm{Q}_{\mathrm{r}}\right)$, actual evapotranspiration (AET) and deep percolation (DP). The difference between the input and output estimates the soil moisture balance $(\Delta S)$. 


\section{Data Collection}

Daily rainfall, daily volumes of irrigation water issued, extent of land cultivated during the season and total paddy production in the scheme were obtained from the Irrigation Department for the period from 2005 to 2014 as shown in Table 1. Some of the seasons had to be omitted from the analysis since data on all aspects, as mentioned above, were not available. The daily pan evaporation values were collected from Bathalagoda Rice Research Institute, which is the nearest rainfall station to the irrigation scheme, and is expected to represent the $\mathrm{IL}_{3}$ AER.

Table 1. Selected cultivation seasons at Hakwatuna Oya Irrigation scheme for the study

\begin{tabular}{|c|c|c|c|c|c|c|c|c|c|}
\hline \multirow{2}{*}{$\begin{array}{c}\begin{array}{c}\text { Cultivation } \\
\text { season }\end{array} \\
\text { Yala }\end{array}$} & \multicolumn{9}{|c|}{ Year of cultivation } \\
\hline & 2005 & 2006 & 2007 & 2008 & & 2011 & 2012 & 2013 & 2014 \\
\hline Maha & $2005 / 06$ & & $2007 / 08$ & $2008 / 09$ & $2009 / 10$ & $2011 / 12$ & & $2013 / 14$ & \\
\hline
\end{tabular}

Soil samples representing the study area (head, middle and tail sections of both left and right canals of the irrigation scheme) were collected using soil auger method from the root zone and analyzed using the Pressure Plate Apparatus to find the Field Capacity (FC) and the Permanent Wilting Point (PWP). The depth of root zone is required to calculate the water content within the root zone of paddy crop which depends on many factors. The farmers in the Hakwatuna Oya irrigation scheme, like many other systems, use farm machinery for land preparation. The root zone thus confines itself to the disturbed soil depth as the hardpan develops in the bottom of the plough layer depending on the type of machinery used. The mould board plough attached to four wheel tractor can plough up to $20-30 \mathrm{~cm}$ depth (Mohamed et al., 2013). Therefore, the depth of root zone to calculate soil moisture parameters for the soil moisture balance was taken as $25 \mathrm{~cm}$. A recent study has shown that the highest clay accumulation was recorded in 20-30 cm layer in puddled low land paddy soil in Puliyankulama in Anuradhapura (Weerasooriya et al., 2015).

Using the above information, the soil water characteristics for the calculation of soil moisture balance was estimated and are given in Table 2 .

Table 2. Estimated soil moisture characteristics for paddy soils in Hakwatuna Oya irrigation scheme

\begin{tabular}{lccc}
\hline Characteristics & $\begin{array}{c}\text { Percentage in } \\
\text { volumetric basis }\end{array}$ & $\begin{array}{c}\text { Depth of water in } \\
\text { mm per m depth of } \\
\text { soil }\end{array}$ & $\begin{array}{c}\text { Depth of water } \\
\text { within 250 mm } \\
\text { depth of soil }\end{array}$ \\
\hline $\begin{array}{l}\text { Soil Texture } \\
\text { Field Capacity }\end{array}$ & $34 \%$ & $\begin{array}{c}\text { Sandy Clay Loam } \\
\text { Permanent Wilting }\end{array}$ & $340 \mathrm{~mm}$ \\
$\begin{array}{l}\text { Point } \\
\text { Available Water }\end{array}$ & $21 \%$ & $210 \mathrm{~mm}$ & $85 \mathrm{~mm}$ \\
$\begin{array}{l}\text { Maximum Allowable } \\
\text { Depletion }\end{array}$ & $13 \%$ & $130 \mathrm{~mm}$ & $52.5 \mathrm{~mm}$ \\
\hline
\end{tabular}




\section{Data Analysis}

\section{Water Supply}

The contribution of irrigation issues as an input was calculated by dividing the total irrigation issued for the day by the total extent cultivated during the season to obtain the irrigation water issue as a depth in $\mathrm{mm}$. The total input is calculated by summing up of the total daily rainfall received $(\mathrm{mm})$ and the daily irrigation water issued $(\mathrm{mm})$.

\section{Runoff}

The Curve Number method is commonly used to estimate runoff produced from small agricultural watersheds (SCS, 1971). In this method, it is assumed that the surface runoff take place when the rainfall rate exceeds the infiltration rate. The rainfall of the past 5-days is taken in to consideration for the estimation of antecedent moisture conditions (AMC) to estimate the runoff $\left(Q_{r}\right)$ given in equation 2. The runoff is calculated in inches using precipitation data in inches $(\mathrm{P})$ and the curve number $(\mathrm{CN})$ is estimated according to the Hydrological soil group and antecedent moisture condition (Reshmidevi, 2008).

$$
Q_{r}=\frac{[P-0.2\{(1000 / C N)-10\}]^{2}}{P+0.8\{(1000 / C N)-10\}}
$$

\section{Evapo transpiration (ET)}

Evapotranspiration is defined as the combination of water evaporated from soil and water transpired from a crop. In this study the reference evapotranspiration $\left(\mathrm{ET}_{0}\right)$ was calculated by multiplying the measured pan evaporation $\left(\mathrm{E}_{\mathrm{p}}\right)$ by the pan coefficient $\left(\mathrm{K}_{\mathrm{p}}\right)$ for a Class A pan (FAO, 1977) using equation 3.

$$
E T_{0}=E_{P} * K_{P}
$$

\section{Potential evapotranspiration (PET)}

The potential evapotranspiration was calculated by multiplying the reference evapotranspiration $\left(\mathrm{ET}_{\mathbf{0}}\right)$ by the crop factor $\left(\mathrm{K}_{\mathrm{c}}\right)(\mathrm{FAO}, 1998)$. The crop factor varies with each growing stage. The $\mathrm{K}_{\mathrm{c}}$ value for each growth stage for paddy is obtained from FAO (1977).

\section{Actual Evapotranspiration (AET)}

When there is sufficient water available, the crop will withdraw water to satisfy potential evapotranspiration (PET). However, if the soil moisture deficit is high, the roots cannot attract sufficient water and transpire at the potential rate. Then the actual evapotranspiration (AET) will be less than the potential value (PET). The point which determines whether AET is less than PET is the maximum allowable depletion (MAD), which is considered as $50 \%$ of the available water (FAO, 1998). This 50\% MAD was also used in a previous study for paddy by Wickramaarachchi et al. (2002). There are several ways of relating AET and PET. The method proposed below is suitable when rainfall or irrigation does occur during periods of high moisture deficit which is more common in irrigation systems in the dry and intermediate zones of Sri Lanka. Equation 4 is used in performing soil moisture balance calculation in this study where PS is defined as potential change in soil storage $(\mathrm{mm})$. 


$$
P S=(P+I)-\left(Q_{r}+P E T+D\right)
$$

The potential change in storage (PS) and actual change in storage (AS) are considered equal if the soil moisture deficit within the root zone is less than the MAD. If soil moisture deficit is more than the maximum allowable depletion, the plant cannot uptake required amount of moisture to satisfy its transpiration requirement. Therefore, the actual soil moisture loss (AS) is less than the potential soil moisture loss (PS). Within this moisture stress zone, the AS is considered as $0.5 \mathrm{PS}$. This relation should only be used when soil moisture storage is positive according to the equation 5. If it is negative (i.e. if the $\mathrm{P}+\mathrm{I}$ exceed the PET $+\mathrm{Q}_{\mathrm{r}}$ ) AET occurs at the potential rate (PET).

$$
A E T=(P+I)-\left(Q_{r}+D+A S\right)
$$

\section{Soil Moisture Deficit (SMD)}

\section{Total soil moisture deficit (stress)}

Since the cultivation season begins with continuous irrigation water supplied to saturate the soil profile, the analysis was conducted under the assumption that there is no soil moisture deficit in the root zone at the beginning of each cultivation season. The daily soil moisture balance or moisture accounting was then performed using equation 1 . The relevant equations as described above were used to determine the parameters in equation 1. If the SMD exceeds the MAD, the plant goes under water deficit.

The number of days during which the plants go under deficit was calculated by counting the days when the SMD exceeded the MAD during the growing season. The amount of water deficit in mm on the plant was calculated by subtracting the MAD from the SMD of that day. When the SMD and the MAD is plotted with the days of cultivation for a season, the total soil moisture deficit for the season is represented by the area under the SMD curve above the MAD level. Since farmers of Hakwatuna Oya irrigation scheme cultivate $31 / 2$ month varieties of paddy, total number of days per cultivation season for 105 days paddy was estimated at 120 days which includes 15 days for land preparation as recommended by the Residential Project Managers Office at Hakwatuna Oya irrigation scheme.

\section{Regression analysis}

A simple linear regression was conducted between the paddy productivity $(\mathrm{t} / \mathrm{ha})$ of the irrigation system and the soil moisture deficit to find the relationship between them. The paddy productivity (or system productivity which is more relevant in terms of irrigation system water management) in $\mathrm{t} / \mathrm{ha}$ was calculated by dividing the total paddy production ( $\mathrm{t}$ ) from the system by the total cultivated area (ha). The soil moisture deficit is represented in two ways. One of the ways to represent the soil moisture stress is to find the total number of days that plant goes under stress. The severity of soil moisture deficit is calculated by multiplying the days under which the plants go under stress by the amount of water deficit (mm.days). Both these indicators were calculated for Yala and Maha cultivation seasons from 2005 to 2014 and were used as independent variables. 


\section{RESULTS AND DISCUSSION}

\section{Well and poorly performing seasons}

\section{Yala Season}

The amount of soil moisture deficit $(\mathrm{mm})$ for a growing season in daily basis is represented by the soil moisture deficit graph. Figures 1 and 2 represent the soil moisture deficit for a well performed and poorly performed Yala seasons of Hakwatuna Oya irrigation system respectively. The 2006 Yala was selected as a well-performed season because the farmers have cultivated all 2,579 hectares. According to the Fig. 1, the system has received sufficient water just as the soil moisture depletes to the MAD level by either rainfall or irrigation so that the crop did not face a water deficit. The paddy productivity was reported as $4.4 \mathrm{t} / \mathrm{ha}$ during this season and is found to be not far from $4.5 \mathrm{t} / \mathrm{ha}$, the national average paddy productivity assigned for Kurunegala district for the Yala season of 2006.

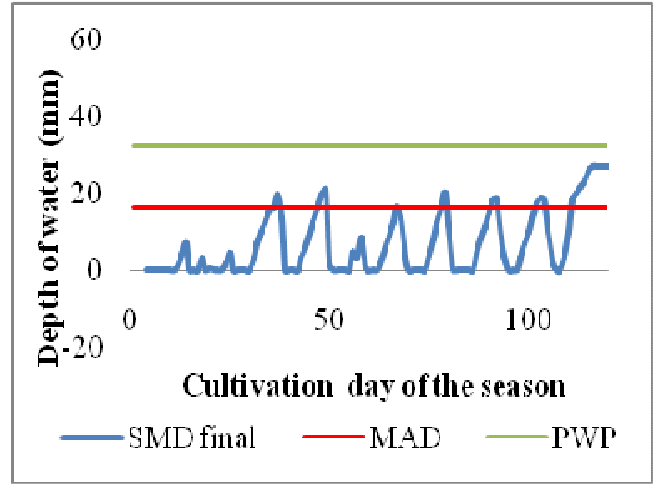

Fig. 1. SMD, MAD and PWP for 2006 Vala season

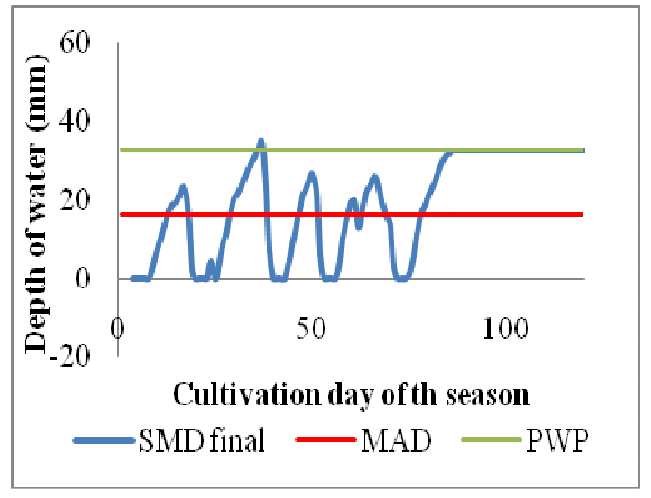

Fig. 2. SMD, MAD and PWP for 2005 Vala season

The Yala season of the year 2005 was selected as a poorly performed season because the farmers have cultivated only 1,000 hectares of land. The crops had a total of $2,470.89$ mm.day of water deficit. During this season, the system productivity is estimated as 3.85 $\mathrm{t} / \mathrm{ha}$. This value is below $4.1 \mathrm{t} / \mathrm{ha}$, the national average paddy productivity for Kurunegala district for the Yala season of 2005. The high water deficit condition on the crops during late growing stages may have contributed to this low productivity.

\section{Maha Season}

Figures 3 and 4 shows the soil moisture deficit $(\mathrm{mm})$ for a growing season on daily basis, the maximum allowable depletion level (MAD) and the permanent wilting point (PWP) for a well performed and a poorly performed Maha seasons respectively. Unlike Yala season, the farmers in the irrigation scheme have cultivated paddy in all 2,579 hectares of land for Maha seasons since there is more rainfall. The 2007/08 Maha was selected as a well-performed season because the total water deficit undergone by the crop during this season was $62.1 \mathrm{~mm}$. The soil moisture deficit exceeded the MAD level only at the latter part of the crop growth as shown in Fig. 3. During this season the system total production was $15,418 \mathrm{t}$ with a paddy productivity of $5.98 \mathrm{t} / \mathrm{ha}$. This productivity is higher than the national average paddy 
productivity of 4.76 t/ha assigned for Kurunegala districts for Maha 2007/08. Adequate soil moisture availability within the root zone during the growing season may have contributed to the higher productivity of paddy within the Hakwatuna Oya irrigation scheme.

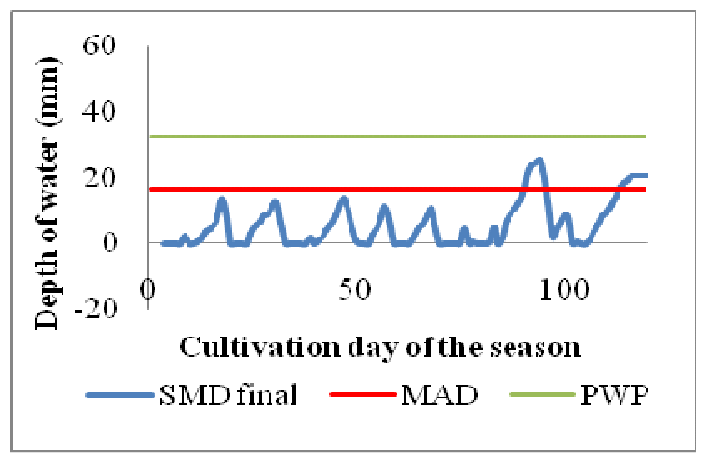

Fig. 3. SMD, MAD and PWP for 2007/08 Maha season

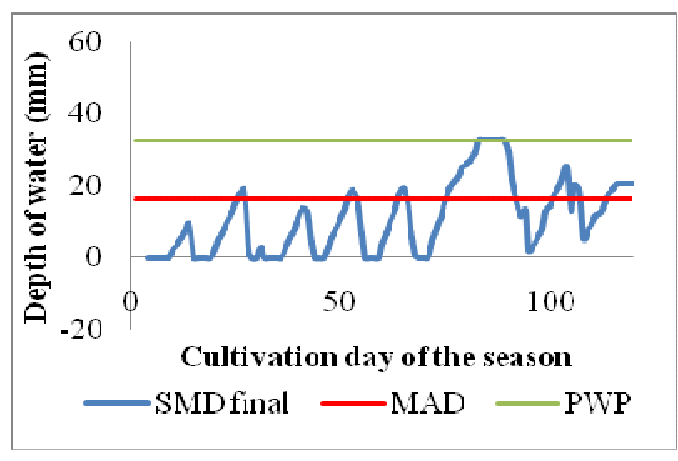

Fig. 4. SMD, MAD and PWP for 2008/09 Maha season

The 2008/09 Maha season was considered as a poorly performed season because there was a crop failure of 184.6 hecatares, though the irrigation water was issued for all the area cultivated. During this season, the crop has faced a total of $270 \mathrm{~mm}$.day of water deficit. The soil moisture deficit is so severe that it has reached to PWP. Because of the high moisture deficit experienced during this season, the paddy productivity has gone down to $3.2 \mathrm{t} / \mathrm{ha}$ which is lower than the national paddy productivity of $4.78 \mathrm{t} / \mathrm{ha}$ for Kurunegala district for the Maha season of 2008/2009. The high water deficit condition on the crops during the reproductive stages may have contributed to the lower productivity.

\section{Paddy productivity and soil moisture deficit}

\section{Yala Season}

Fig. 5 illustrates results of linear regression between paddy productivity and total number of days during which the paddy crop has gone under moisture deficit for Yala seasons from 2005 to 2014. There is a very slight decrease of productivity with increased number of days under moisture deficit as expected though it is not statistically significant. As shown in Fig. 6 , there is also a very poor relationship between paddy productivity and severity of soil moisture deficit expressed by mm.days. The most probable reason for this could be due to the errors in estimating the parameters in the soil moisture balance equation, especially the depth of irrigation water issued. The extent cultivated, as reported by the Department of Irrigation, during Yala season varies and the total irrigation water issues were divided by this reported extent cultivated to get the depth of irrigation. It is possible that farmers may have abstracted water illegally to other areas irrespective of the assigned extent under cultivation. This might have contributed to the comparatively poor statistical relationships between paddy productivity and soil moisture deficit during Yala season.

\section{Maha Season}

Fig. 7 and 8 illustrates the linear regression analysis between paddy productivity and the total number of days under water deficit and severity of moisture deficit in mm.days respectively for Maha seasons. The correlation between paddy productivity and total number of days 
under moisture deficit in Fig. 7 displays a decreasing inclination, and the results are found to be statistically significant $(\mathrm{p}=0.03)$. In addition, $72 \%$ of the paddy productivity variation can be explained by the total number of days under which the plant has gone under soil moisture deficit since $\mathrm{R}^{2}=0.72$.

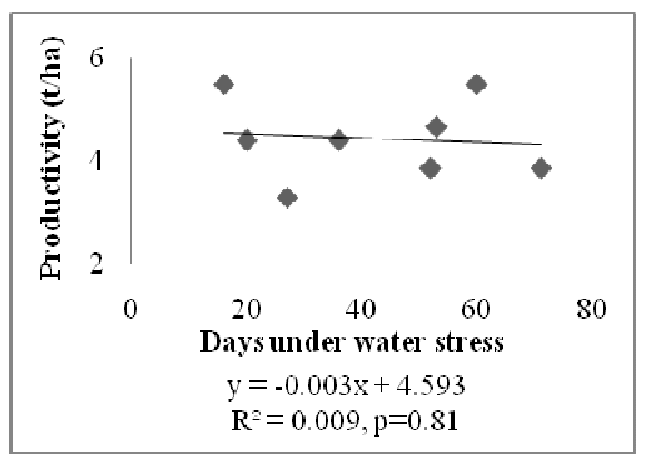

Fig. 5. Paddy productivity and total number of days under moisture deficit in Yala season

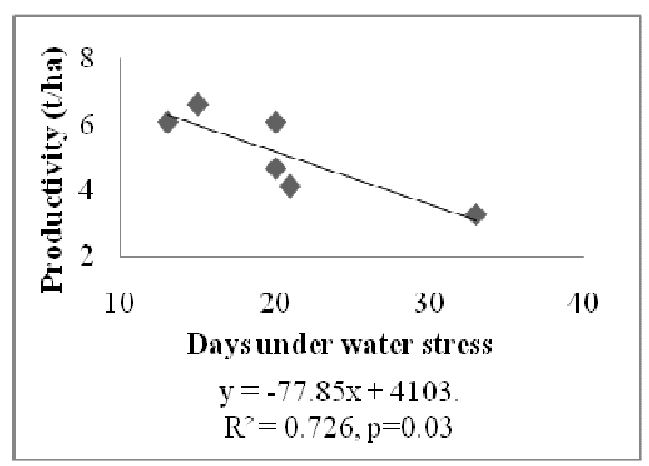

Fig. 7. Paddy productivity and total number of days under moisture deficit in Maha season

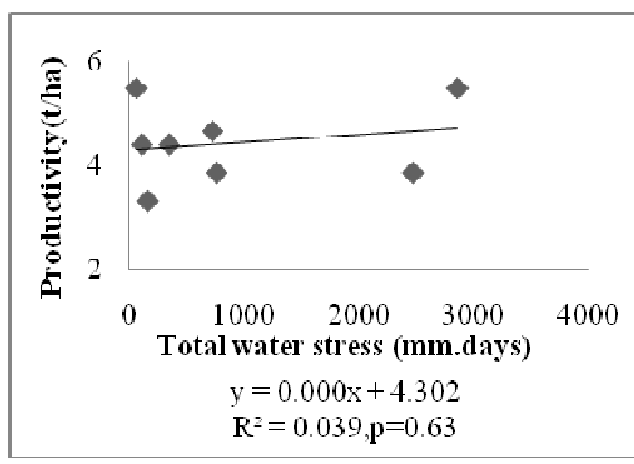

Fig. 6. Paddy productivity and total moisture deficit during Yala season

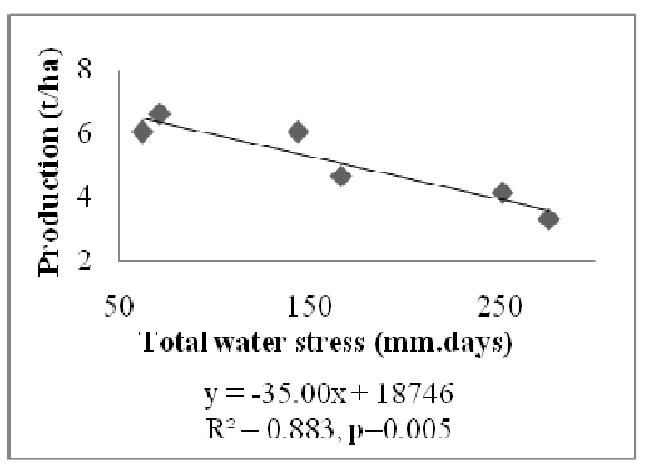

Fig 8. Paddy productivity and total moisture deficit during Maha season

The severity of moisture deficit always has a strong relationship to the paddy productivity compared to the total number of days during which the plants expose to soil moisture deficit conditions. A day with a soil moisture deficit is counted as one, even if soil moisture deficit exceed the MAD level even by $1 \mathrm{~mm}$. This low value of water deficit may have a minimum impact on the productivity. However, the total moisture deficit given in mm.days (i.e. the area under the curve of soil moisture deficit and maximum allowable water content) provide the severity of moisture deficit and, therefore considered as a much better indicator in affecting the paddy productivity. As shown in Fig. 8, about $88 \%$ of the variation of paddy productivity could be explained by the total soil moisture stress. 
The overall results establish that the paddy productivity is influenced by the soil moisture stress during the Maha season. During Maha season, farmers cultivated all 2,579 ha and, as a result, the depth of irrigation water was calculated by dividing the total irrigation water issued by 2,579 ha, thus eliminating any errors in calculating the irrigation issue in the water balance equation.

\section{CONCLUSION}

The results indicated that the paddy productivity in a large irrigation scheme depends on the soil moisture stress undergone by the crop during the cultivation season. This paddy productivity or irrigation system productivity decreases with the increased number of days during which the plants were under soil moisture stress. This impact is more pronounced with the severity of soil moisture stress, as expressed in total soil moisture stress in mm.days during the season.

\section{ACKNOWLEDGEMENT}

This work was carried out with the aid of a grant from the International Development Research Centre, Ottawa, Canada. The financial assistance provided is greatly acknowledged.

\section{REFERENCES}

Bhuiyan, S. I. (1992). Water management in relation to crop production: Case study on rice. Outlook Agric. 21(4), 293 - 299.

Ekanayake, I.J., Steponkus, P.L. and De Datta, S.K. (1989). Spikelet sterility and flowering response of rice to water stress at anthesis. Ann. Bot. 63, 257 - 264.

FAO. (1977). Crop water requirements: FAO irrigation and drainage. Paper 24. Food and Agriculture Organization, Rome.

FAO. (1998). Crop evapotranspiration: FAO irrigation and drainage. Paper 56. Food and Agriculture Organization, Rome.

Fukai, S. and Inthapan, P. (1988). Growth and yield of rice cultivars under sprinkler irrigation in south-eastern Queensland. 3. Water extraction and plant water relations. Aust. J. Exp. Agric. 28, 249-252.

Hanson, A.D., Peacock, W.J., Evans, L.T., Arntzen, C.J. and Khush, G.S. (1990). Drought resistance in rice. Nature. 345, 26-27.

Inthapan, P. and Fukai, S. (1988). Growth and yield of rice cultivars under sprinkler irrigation in south-eastern Queens- land. 2. Comparison with maize and grain sorghum under wet and dry conditions. Aust. J. Exp. Agric. 28, 243-248. 
Mohamed, A.I.L, Ginigaddara, G.A.S, Kahandage, P.D, Fernando, A.P.S and Bandara, A.M.K.R. (2013). Effect of Plough Layer Depth on Growth and Yield of Rice in Dry Zone of Sri Lanka. Proceeding of the 3rd Annual Research Symposium, Rajarata University, Sri Lanka.

Pantuwan, G., Fukai, S., Co-oper, M., Rajatasereekul, S. and O’Toole, J.C. (2000). Field screening for drought resistance. In: Increased Lowland Rice Production in the Mekong Region: Proc. Int. Workshop. Vientiane, Laos. pp. 69-77.

Perera. A.C.S., Punyawardena, B.V.R. and Gunawardena, E.R.N. (2014). Occurrences of droughts in the Hakwatuna Oya Watershed of Sri Lanka. Proc. $5^{\text {th }}$ International Conference on Sustainable Built Environment. December 2014, Kandy, Sri Lanka. pp. 226-233.

Punyawardena, B.V.R. (2008). Rainfall and agro-ecological regions of Sri Lanka. Natural Resources Management Centre, Department of Agriculture, Peradeniya. pp. 67-74.

Reshmidevi, T.V., Jana, R. and Eldho, T. I. (2008). Geospatial estimation of soil moisture in rain-fed paddy fields using SCS-CN-based model. Agr Water Manage. 95(4), 447-457.

Sarkarung, S., Pantuwan, G., Pushpavesa, S., Tanupan and Germplasm, P. (1997). Development for Rain fed Lowland Ecosystems: Breeding Strategies for Rice in DroughtProne Environments; Proc. Int. Workshop: UbonRatchathani, Thailand. pp. 43-49.

SCS. (1971). Hydrology, National Engineering Handbook. USDA Soil Conservation Services. Washington, DC.

Tuong, T.P. and Bouman, B.A.M. (2003). Rice production in water-scarce environments. Water productivity in agriculture: Limits and opportunities for improvement. 1, 13-42.

Weerasooriya, G.V.T.V., Jayatissa, D. N. and Ranbanda, M. (2015). Bulk soil proportions as determinants of the soil composition strength of puddle low land paddy soils in Sri Lanka. Journal of Tropical Agricultural Research. 26(3), 561-568.

Wickramaarachchi, T.N., WIjesekara, N.T.S and Gamage, N.P.D. (2002). Water scheduling for better yield in paddy cultivation - a case study from Mahaweli system H of Sri Lanka, Engineering journal of the Institution of engineers Sri Lanka. 2, 38-44.

Zubair, L., Rao, S. A. and Yamagata, T. (2002). Modulation of Sri Lankan Maha rainfall by the Indian Ocean Dipole: Geophysical research letters. 30(2), 1063. 